\title{
FELA OR UNIFORM COMPENSATION FOR ALL WORKERS?*
}

\author{
Reginald Parker $\dagger$
}

The Federal Employers' Liability Act, ${ }^{1}$ despite its title, is an act regulating the work-injury liability, not of employers in general, but merely of railroads. The predecessor of the present statute was similarly limited to railroad employees. ${ }^{2}$ However, a Supreme Court then anxiously guarding a narrow interpretation of the Constitution's commerce clause declared the Act unconstitutional as not expressly confined to the regulation of interstate commerce. ${ }^{3}$ The rgo8 Act therefore made it clear that the law was to apply only to carriers "by railroad while engaging in commerce between any of the several states. ..." The I939 amendment extended the coverage to railroad employees any part of whose duties is the "furtherance" of or "in any way directly or closely and substantially affect" interstate commerce." Despite this broadening of scope, the FELA is still confined to railroad employees."

And even within this limit, the $\mathrm{Act}^{\top}$ is not a railroad workers' compensation statute, such as the Longshoremen's and Harbor Workers' Compensation Act ${ }^{8}$ or the Federal Employees' Compensation Act. ${ }^{9}$ Rather, it is a statute modifying the duties under tort law of railroads toward their employees. Under the common law of torts, the master is liable to his servants for negligence, particularly in providing them with a safe place to work as well as with safe tools, ${ }^{10}$ and has a duty to help them when in peril. ${ }^{11}$ These duties, however, are or at least were ${ }^{12}$ subject to con-

* This is an expanded version of a paper presented at the round-table meeting on workmen's compensation, during the annual convention of the Association of American Law Schools on December 29, 1952. The study expresses the opinion of the author, not of the National Association of Claimants' Compensation Attorneys or of any other group.

† Lecturer in Law, Northeastern University; Assistant Editor-in-Chief, NACCA Law JournaL. Formerly, Professor of Law, University of Arkansas. Author, Administrative Law: A TExT (BobbsMerrill 1952).

${ }^{1} 35$ STat. 65 (1908), as amended, 36 STat. 29 I (19ro), 53 STat. I404 (I939), 45 U. S. C. $\$ \$ 51-60$ (1946).

34 STAT. 232 (1906).

${ }^{3}$ Howard v. Illinois Central R. R., 207 U. S. 463 (r908). See Miller, Workmen's Compensation for Railroad Employees, 2 Loyola L. Rev. 138, I46 (1944).

35 Stat. 65 (1908).

53 Stat. 1404 (1939), 45 U. S. C. \$51 (1946).

'See infra, note 22.

7The title of the FELA is misleading. It is not a "federal employer" law (cf. infra, note 9) but a (federal) law pertaining to employers; and it does not pertain to "employers" as such, either, because it merely applies to railroads.

${ }^{8} 44$ STAT. I424 (1927), 33 U. S. C. \$901 (1946).

39 Stat. 742 (r9I6), as amended, 5 U. S. C. \$75I (1946).

${ }^{10}$ See Prosser on Torts 506-509 (194I).

II Id. at 193 .

${ }^{12}$ Modern workmen's compensation laws and a more favorable attitude toward labor have no doubt made important inroads on the employer-minded common law. See, e.g., Baumgartner v. Holslin, 52 N. W. $2 \mathrm{~d} 763$ (Minn. I952) (farm worker, though experienced, recovers in tort for injury from 
siderable restrictions, which made the lot of the worker in common-law countries somewhat less desirable than that of his brethren under the civil law. His negligence suit against the employer is or was open to the defense of his contributory negligence, which was not hard to adduce; after all, it can nearly always be said that with greater care the employee could have avoided an accident that occurred under circumstances over which he was likely to have greater control than his master. And if he was not contributorily negligent, the easily proved fact that he had "assumed" the risks of his employment stood up as another defense against his claim. Furthermore, even if the servant had neither carelessly contributed to nor assumed the dangers that brought about his accident, the fault of a fellow servant could be used under a particularly harsh doctrine in order to defeat the tort action. Lastly, it was and still is one of the most confusing vestiges of our tort law that the "mere" violation of a statutory duty, such as perchance a law prescribing safety measures, is not in itself proof of negligence. ${ }^{13}$

The FELA, as amended, has done away with the defense of contributory negligence as we know it and replaced it by comparative negligence of maritime and European civil law, which works merely in mitigation of damages. It has completely abolished the fellow servant doctrine, which means that respondeat superior is applicable and the railroad is liable regardless of who within the scope of his railroad employment caused the accident. Assumption of risk is no longer a defense, not even in mitigation of damages, which, oddly enough, means that when the injured railroad man could merely foresee the danger but negligently disregarded it, he loses some of his claim under the comparative negligence doctrine; but if he knew of the danger and willfully assumed it, he recovers fully. ${ }^{14}$

Finally, the Safety Appliance Acts ${ }^{\mathbf{1 5}}$ as interpreted by the courts have established the rule that any violation of these acts, or of any regulation issued thereunder, imposes absolute liability on the railroad. The problem of negligence may not be raised and it is error to charge the jury with the question in safety appliance cases. ${ }^{16}$ The scope of this rule is very far-reaching and at times brings the FELA into the close vicinity of an insurance law or, in other words, of workmen's compensation. Once the failure to work properly of a safety appliance (such as power driving-wheel brakes, automatic couplers, grab irons, bell ringers, boilers, or sanding apparatus) is shown, there remains only the question of causation. It makes no difference why the ap-

poison gas emerging from feed silo); Heinlen v. Martin Miller Orchards, 242 P. 2d I054 (Wash. r952) (orchard worker recovers for injury inflicted by brush-shredding machine whose defectiveness he knew though not the risk of harm resulting therefrom). And see Jenkins v. Banks, 87 A. 2 d 908 (Me. I952) (duty to furnish safe tools, if any, exists even toward contractor); Enid Transfer \& Storage Co. v. Mollenhauer, 25 I P. 2d ro68 (Okla., 1952); Leflar, Negligence in Name Only, 27 N. Y. U. L. Rev. 564, 576 (1952).

${ }^{13} \mathrm{See}$ the discussion in Prosser on Torts $264-276$ (194r).

It See Byler v. Wabash R. R., I96 F. 2d 9 (8th Cir. 1952) (contractual risk-assumption no defense); Miller, Workmen's Compensation for Railroad Employees, 2 LoyoLA L. Rev. 138, I50-5I (I944). ${ }^{16} 27$ STAт. 53 r (r 893 ), as amended, 45 U. S. C. $\$ \$ 1-46$ (I946).

${ }^{20}$ O'Donnell v. Elgin, Joliet \& Eastern Ry., 338 U. S. 384 (I949); Lilly v. Grand Trunk Western R. R., 317 U. S. 481 (1943). 
pliance failed to work; nor may the railroad be allowed to prove that it exercised due diligence in taking care of it. ${ }^{17}$ And as to causation, a so-called "contributory proximate"18 cause is all that need be shown. Thus an engineer was killed by another train when he got out of his engine to attempt to make the sanding apparatus work. The failure of the sander was held to be the cause of his death, and the arguments of remoteness and indirectness were rejected. ${ }^{\mathbf{1 0}}$

This mode of legislation has created a friendly atmosphere toward injured railroad workers in the courts, both state and federal. ${ }^{20}$ The sufficiency of the evidence is a federal question to be determined by the holdings of federal decisions. ${ }^{21}$ Verdicts are high, probably higher than they would be in ordinary tort suits for similar injuries. And it need not be emphasized that, stripped of their most powerful common-law defenses, particularly contributory negligence and assumption of risk, the defendant railroads under the FELA have less of a chance to prevail than ordinary defendants in negligence suits. In spite of all this, however, the narrowness of the scope of the FELA must not be overlooked. The Act does not apply to some workers engaged in quite similar tasks and subject to the same perils as railroad employees, such as Pullman car porters or railway express employees. ${ }^{22}$ It does not apply ${ }^{23}$ where the worker received a work injury through a third party's fault and it has been held that this excludes from the applicability of the Act even suits against third-party railroads, i.e., railroads other than the one employing the injured worker. ${ }^{24}$ It is, however, not necessary here to explore the size and limits of the exceptions, as well as of the exceptions to the exceptions, because, as we shall try to demonstrate, the special status of the railroader appears to be an outmoded conception of the law.

American workers, apart from railroad employees, fall into several groups as far as their rights to recover for work injuries are concerned. Domestic servants

${ }^{17}$ See Forer and Richter, The Federal Employers' Liability Act, I2 F. R. D. 13, 45 (1952).

${ }^{18}$ Coray v. Southern Pac. Co., 335 U. S. 520, 523 (1949); Eglsaer v. Scandrett, 15I F. 2d 562 (7th Cir. 1945); Givens v. Missouri, K. \& T. R. R., I95 F. 2d 225, 229-30 (5th Cir,. 1952).

${ }_{10}$ Warning v. Thompson, 249 S. W. $2 d$ 335, 339 (Mo. 1952); Anderson v. Baltimore \& O. R. R., 96 F. $2 d 706$ (2d Cir. 1938).

${ }^{20}$ An FELA action may be brought in either the state or the federal courts regardless of the partics' citizenship or the amount involved, but if brought in a state court it may not be removed to a federal court. $3^{6}$ Stat. 29 I (rgro), as amended, 62 STAT. 989 (1948), 45 U. S. C. $\$ 56$ (1946). And sec 28 U. S. C. \$1445. For a good survey of some of the problems involved, sce Note, Fedcral Employers' Liability Act in Inconvenient State Courts, 5 U. of FLA. L. Rev. 72 (1952). And see Missouri ex rel. So. Ry. v. Mayfield, 340 U. S. I (r950), 6 NACCA L. J. I68, 30 N. C. L. Rev. 168 (1952), for a discussion of a state's power to deny access to its courts in FELA suits.

${ }^{21}$ Jesionowski v. Boston \& Maine R. R., 329 U. S. 452 (1947); Brady v. Southern Ry., 320 U. S. 476 (1943); Propper v. Chicago, R. I. \& P. R. R., 54 N. W. $2 d 840$ (Minn. 1952). And see Note, The Directed Verdict and Applicability of State Procedural Rules in FELA Cases, 27 IND. L. J. 536 (1952).

${ }^{22}$ Wells, Fargo \& Co. v. Taylor, 254 U. S. 175 (1920) (express messenger); Robinson v. Baltimorc \& O. R. R., 237 U. S. 84 (1915) (Pullman porter, even though collecting tickets).

${ }^{23}$ I.e., the plaintiff is confined to the common-law remedies and subjected to its defenses.

${ }^{24}$ Patton v. Baltimore \& O. R. R., r97 F. 2d 732 (3d Cir, 1952); Hartley v. Baltimorc \& O. R. R., 194 F. 2d 560 (3d Cir. 1952); Risberg v. Duluth, M. \& I. Ry., 233 Minn. 396, 47 N. E. 2d 113 (1951), cest. denied, 342 U. S. 832 (195I). The FELA does apply, on the other hand, to clerical personnel. Lillic v. Thompson, 332 U. S. 459 (1947). 
and unfortunately farm workers ${ }^{25}$ are usually confined to the common law of torts with its defenses-still valid to a varying degree-of contributory negligence, assumption of risk, and the fellow servant doctrine; and the same is true of those other workers whom the various state laws have chosen to exclude from workmen's compensation. ${ }^{28}$ Maritime workers other than longshoremen and harbor workers have a variety of rights in case of injury. One of them, the right to maintenance and cure, approximates workmen's compensation and, indeed, health insurance. ${ }^{27}$ 'The other seamen's rights are closely akin to those accruing to railroad men under the FELA, ${ }^{28}$ yet they do go beyond the latter in that the boat owner's liability for "unseaworthiness" of the vessel creates an absolute liability not only for specific appliances (as for railroads under the Safety Appliance Acts) but also for anything that is a part of the boat ${ }^{29}$ - under a recent decision even the vicious propensities of a fellow crew member. ${ }^{30}$ In view of these three factors-negligence liability of the boat owner to the exclusion of the common-law defenses; absolute liability for any unseaworthiness; and liability for maintenance and cure in cases not necessarily involving accidents at all-it may be said that seamen have the most far-reaching rights.

Longshoremen and harbor workers are covered by a federal workmen's compensation act, ${ }^{31}$ as are employees of the Federal Government. ${ }^{32}$ Aside, then, from railroad men and from statutory exceptions such as for farming or domestic work, all other American workers are protected as well curtailed by state workmen's compensation laws. This is so regardless of whether or not the worker is engaged in or furthers interstate commerce.

It is frequently heard that the social protection afforded by state workmen's compensation is inadequate. ${ }^{33}$ The maximum awards for permanent disabilities, total or partial, are pitifully low in many states both as to the limit of weekly pay-

\footnotetext{
${ }^{25}$ The idea that agricultural or horticultural work is not dangerous is actually a myth. Of the 16,500 fatal work accidents in the United States, in 1948 , 4,400, or 26.6 per cent, occurred in farming, which in absolute number of industrial deaths leads all other occupations. The death rate has been steadily falling in other industries, but in farming it has risen and was higher in 1948 than in 1945. Powers, Farm Injuries, 243 New England Journal of Medicine 979 (I950).

${ }^{20}$ See the survey in U. S. Buread of Labor Standards Bull. No. 125, State Workmen's CompensaTION LAWS 4-6 (r950 with I952 supplements); I LARSON, THE LAW OF WORKMEN's COMPENSATION 734$816(1952)$.

${ }_{27}$ Cf. Howe, Rights of Maritime Workers, 6 NACCA L. J. I3I, 133-r35 (1950); Comment, $A d$ mirality-Maintenance and Cure, $50 \mathrm{MrcH}$. L. Rev. 435 (1952).

${ }^{28}$ These are incorporated into the Jones Act. 4I STAT. 1007 (I920), 46 U. S. C. $\$ 688$ (1946); Correia v. Van Camp Sea Food Co., 248 P. 2d 8I (Cal. App. I952); Howe, Rights of Maritime Workers, 5 NACCA L. J. 146, I56-58 (1950).

${ }^{20}$ E.g., a plank used as a walkway between locomotives on board ship. Brabazon v. Belships Co., 103 F. Supp. 592 (E. D. Pa. I952); Howe, Rights of Maritime Workers, 6 NACCA I. J. I3I, I35 (I950).

${ }^{30}$ Keen v. Overseas Tankship Corp., 194 F. $2 \mathrm{~d} 515$ (2d Cir. 1952), I00 U. of PA. L. Rev. I045 (1952).

${ }^{31}$ Supra, note 8. Section 3 of the Longshoremen's Act provides that the Act shall apply only "if recovery for the disability or death through Workmen's Compensation proceedings may not validly be provided by state law." See Western Boat Building Co. v. O'Leary, 198 F.2d 409 (9th Cir. 1952).

"Supra, note 9.

${ }^{33}$ For a diacritical analysis, see ARThuR H. ReEde, Adequacy of Workmen's Compensation (I947). For an outright condemnation see the CIO pamphlet, Workmen's Compensation-A Story of Failure, Economic Outlook, Jan. I952, and the AF of L periodical, The Weekly Dispatch (San Antonio), Nov. I4, 1952, page 2 .
} 
ments and the total maximum benefit a crippled worker may receive. The number of weeks for which payments may be made is arbitrarily and unjustifiably limited. The maximum allowable burial expenses in many states could in these inflationridden days cover hardly more than the funeral bill of a pet cemetery. And death benefits are far below any recognized standard of adequacy. ${ }^{34}$

A learned reviewer of my textbook on administrative law has emphasized my friendly disposition toward administrative law. ${ }^{35}$ Yet my faith in agencies has received a blow-albeit not a knockout-upon perusing a recent study that tends to show that workmen's compensation procedure, which is usually ${ }^{30}$ conducted before administrative agencies, is at least not inherently more expeditious or economical than the judicial procedure involved in law suits under the FELA. ${ }^{37}$ On the other hand, even assuming the general validity of the Illinois study, it has also been demonstrated by competent authority ${ }^{38}$ that tort suits under the FELA amount to a lottery in that the plaintiff can never be sure whether or not he can prove his case, i.e., his employer's negligence. In other words, the injured railroad man gets either more than (at times, at least as much as) his fellow worker under workmen's compensation, or nothing at all. ${ }^{39}$

It is, however, not within the purview of this paper to explore and evaluate with apodictic finality the relative merits of either system. For to decide whether certain law is "good" or "bad" is essentially a political task. "Good" law, correctly speaking, is law that is deemed more socially desirable from the speaker's subjective point of view. In other words, it depends on his social, economic and maybe moral Weltanschauung. ${ }^{40}$

${ }^{34}$ For a comprehensive survey, see U. S. Bureau of LABOr Standards Bull. No. 125, op. cit. sitpra note 26.

${ }^{35}$ Madden, Book Review, 5 VAND. L. Rev. 680 (1952).

${ }^{36}$ In five states workmen's compensation claims are administered by the judiciary. U. S. BurEAu of Labor Standards Bull. No. 125, op. cit. supra note 26 , at 42.

37 ALFRed F. ConARd and Robert I. Mejer, Costs of Administering Reparation for Work INjuries in Ilitinois (Graddate College, Universtity of Ilzinots, 1952). See also, Conard, Worlemen's Compensation: Is It More Efficient Than Employers' Liability?, 38 A. B. A. J. Ior I (1952). And sce Richter and Forer, Federal Employers' Liability Act-A Real Compensatory Law for Railroad Workers, 36 Cornell L. Q. 203 (195I). But sce Bancroft, Some Procedtual Aspects of the Cailfornia Workmen's Compensation Law, 40 Calif. L. Rev. 378 (1952), reaching about the opposite result at least as far as California is concerned. See also Dodd, Administration of Workmen's Compensation, 20 Miss. L. J. I68, I7I (I949).

${ }^{38}$ Pollack, Labor Looks at Workmen's Compensation, in Workaren's Compensation Probltas, U. S. Bureau of Labor Standards BulI. No. 156 I4I (1952); Pollack, Workmen's Compensation for Railroad Work Injuries and Diseases, 36 Connell L. Q. 236 (195 I) (Mr. Jerome Pollack is Consultant for the UAW-CIO). And see 2 Larson, The LaW OF Workmen's Compensation 438-440 (1952).

${ }^{39}$ For recent examples chosen at random, where recovery was denied for railroaders' work injuries or deaths, see Moore v. Chesapeake \& O. R. R., $34^{\circ}$ U. S. 573 (195I) (recovery for death denied for want of employer's negligence); Chesapeake \& O. R. R. v. Thomas, r98 F. 2d 783 (4th Cir. 1952) (same); Lamancusa v. Pennsylvania R. R., 104 F. Supp. 833 (E. D. Pa. 1952) (pncumoconiosis); Williams v. Thompson, $25 \mathrm{I} \mathrm{S.} \mathrm{W.} 2 \mathrm{~d} 89$ (Mo. I952) (injury); Atlantic Coast Line R. R. v. Clarke, 59 So. $2 \mathrm{~d} 77^{8}$ (Fla. 1952) (injury); Ellis v. Louisville \& N. R. R., 251 S. W. 2d 577 (Ky. 1952) (silicosis action for $\$ 99,800)$.

"Kelsen, Science and Politics, 45 Am. Pol. Sct. Rev. 641 (195I); Kelsen, General Theory op LAW AND STATE 5 (1945). For a learned critique, see Ofstad, The Descriptive Definition of the Concept "Legal Norm" Proposed by Hans Kelsen, I6 TheoriA, A Swedish J. of Philos. AND PsY. I18 (1950). 
Yet some objective evaluation seems still permissible. If law is a social technique, then "bad" law is necessarily such law as will fail to accomplish the-at times objectively ascertainable-goal of the lawmaker. Professor Beutel not long ago ably demonstrated that observation and experimentation may reach objectively tenable results in regard to the question of whether or not a particular law accomplishes what its makers obviously want and, if not, whether a different law would be an improvement. ${ }^{41}$ The factual study by Conard and $\mathrm{Mehr},{ }^{42}$ if sound (a question that I must leave to competent insurance economists), is of course a very obviously apposite example for experimental and applied jurisprudence in our field of workmen's compensation and railroad tort law.

At times the task of probing into law objectively rather than from a political or policy point of view can be done from the four corners of the law alone, so to speak. ${ }^{43}$ At other times the entire system of related law must be considered in order to evaluate objectively whether a given body of law, from an efficiency point of view, has its justifiable and deserved place in the legal order. Such a law of the latter category is the FELA, which can be said to be obsolescent-or "bad" if the value judgment must be made-if considered as a whole, i.e., against the background of present constitutional law and in comparison with similar law pertaining to other occupational groups. Briefly, there appears to be no longer any good reason for singling out railroad workers and placing them in a special (privileged or underprivileged, depending on the side of the controversy we are on) group.

The validity of the FELA is grounded in the interstate commerce clause of the Constitution. However, as everybody knows, this clause is not what it used to be in Igo6 or Ig08. Indeed, it might be argued that, aside from the Thirteenth and Fourteenth Amendments, the Constitution has never been more sweepingly amended than by the judicial decisions interpreting "interstate commerce" in those years, I937-I94I, that were so decisive in shaping our system of government and control as we now know it. ${ }^{44}$ Turning to the phases only that are of relevance for this study, we find that in Igo8 railroads, indeed, were considered as being engaged in interstate commerce, ${ }^{45}$ but without gross exaggeration we might say there was little else then so regarded. ${ }^{46}$ In our time, however, it is settled that, contrary to former views, the "manufacturer of goods" may be regarded as commerce, ${ }^{47}$ as may be oil drilling, ${ }^{48}$ insurance, ${ }^{49}$ or even the transportation by an oil company of its own oil

${ }^{\$ 2}$ Beutcl, Relationship of Natural Law to Experimental Jurisprudence, 13 OHio. Sr. L. J. 167 (1952).

42 Op. cit. supra, note 37 .

${ }^{43}$ Some time ago I attempted to show the Federal Administrative Procedure Act's innate deficiencies (aside from the political question of the desirability of its provisions) and hence its lack of efficiency in several of its aspects. Parker, The Administrative Procedure Act: A Study in Overestimation, 60 YALE L. J. 582 (195I); Parker, Administrative Law 60-82 (I952).

" For a most dramatic and yet scholarly account of those years see Stern, The Commerce Clause and the National Economy 1933-46, 59 HARv. L. Rev. 645 (1946).

t5 The validity of the Longshoremen's Act is of course grounded on the federal admiralty jurisdiction.

${ }^{10}$ The standard text on constitutional law was a treatise on its limitations. Cooley, A TrEatise on the Constitutional Limitations Which Rest Upon the Legislative Power of the States of the Ameriann Union (8th ed. Carrington, 1927). And see Corwin, Court over Constitution (1938).

${ }^{47}$ Jones \& Laughlin, infra, note $5 \mathrm{I}$.

${ }^{48}$ Warren-Bradshaw Drilling Co. v. Hall, 3 I7 7 U. S. 88 (1942).

${ }^{\circ 0}$ United States v. South-Eastern Underwriters' Ass'n, 322 U. S. 533 (1944). 
through its own pipelines to its own station. ${ }^{50}$ And we find that labor relations as well as the very employment contract itself may be federally regulated ${ }^{51}$ in industries and enterprises not necessarily engaged in but perhaps merely affecting interstate commerce. Thus the labor relations of a landlord with his janitor in a building whose tenants were engaged in interstate commerce were found to be subject to federal regulations ${ }^{52}$ as were those of a contractor and his workers in a case where the contractee-principal was doing commerce-affecting work. ${ }^{53}$ And the NLRA was declared applicable to the workers of a local streetcar line..$^{54}$ In short, there is probably no field of which it may be safely said that Congress could not exercise jurisdiction, and the commerce clause is now recognized as enabling Congress "to allow interstate commerce to take place on whatever terms it may consider in the interest of the national well-being." ${ }^{355}$ Nor is it likely that this trend has come to a standstill. A New Deal Congress made the Wagner Act; yet a Republican Congress, under the sponsorship of Senator Taft and Congressman Hartley, enlarged its scope considerably. Different political parties may change the contents of federal laws, but they will not diminish, I am sure, federal power over a given field once it has been occupied.

The constitutional situation of $\mathrm{Ig} 08$ is, incidentally, not the sole reason why the FELA, despite its sweeping title, was confined to railroad employees. Mining and other dangerous occupations were not interstate commerce in rgo8; but some other activities, such as airplane piloting or bus driving, would no doubt have then been regarded as being in the same constitutional category as railroading, had they existed. Time and technical progress have marched on, but not the law. In 1952 it must strike us as highly anomalous to see railroad men, but not airline or interstate bus line employees (or, pursuant to narrow judicial interpretation of the FELA, sleeping car porters ${ }^{56}$ and railway express employees ${ }^{57}$ ) placed under a special law in regard to their work injuries. This state of affairs is not in accord with the customary pattern of modern justice which attempts to treat like situations equally.

Of course, inequality need not per se be regarded as "unjust" as long as it has a justifiable ${ }^{58}$ basis. If in medieval law the serf was treated differently from the baron, that was in accordance with the concept of justice, at least of the ruling classes. We do not object to a Wage and Hour Law that exempts from its protective provisions executive and professional as well as a great many other employees

${ }^{50}$ Champlin Refining Co. v. United States, 329 U. S. 29 (1946).

${ }^{51}$ National Labor Relations Board v. Jones \& Laughlin, 30r U. S. I (I937) (NLRA constitutional); United States v. Darby Lumber Co., 312 U. S. 100 (I94I) (FLSA constitutional). And sce Stern, supra, note 44 .

5 A. B. Kirschbaum Co. v. Walling, $3 \times 6$ U. S. 517 (1942).

${ }^{83}$ Warren-Bradshaw, supra, note 48; Walling v. McCrady Construction Co., 156 F. 2d 932 (3d Cir. 1946).

Et National Labor Relations Board v. Baltimore Transit Co., r40 F. 2d 5I (4th Cir. 1944), cert. denied, 32I U. S. 795 (1944).

${ }^{56}$ Stern, supra, note 44 , at 946 .

so Supra, note 22.

57 Ibid.

${ }^{58}$ I will certainly not be suspected of being a natural lawyer. See Parker, Natural Latu and Kelsenism, I3 Oнro. Sr. L. J. r6o (1952). 
for ascertainable reasons that were convincing at any rate to the lawmakers. Likewise may we justify the regionally different treatment of otherwise alike events. If, under state workmen's compensation laws, life is worth at most a mere $\$ 6,600$ in Virginia whereas in Oklahoma it is valued up to $\$ 3,500$, this is justifiable-and hence "just" if the term is desired-to any believer in a federal system of government: even as the laws of divorce or the penalties for homicide may differ from state to state, there may be different compensation benefits for life and limb in the several states. And a federal workmen's injury law confined to railroad employees was perhaps justifiable in Igo8 under the Constitution as we then had it. It is no longer justifiable today.

To leave injured railway workers to state workmen's compensation would create constitutional, though not regional, uniformity. It was not possible in Igo6 and I 908 when but few states had workmen's compensation laws, ${ }^{59}$ whose constitutional validity was considered dubious. ${ }^{60}$ It might be quite feasible today. Yet, to turn the clock back and give railroaders to the states would meet strong opposition in all quarters concerned, ${ }^{61}$ in view of both the low compensation awards prevailing in nearly all the states and the endless interstate jurisdictional disputes this solution would no doubt create. ${ }^{62}$

The only road toward justice-i.e., the elimination of unjustifiable distinctions between worker and worker-appears to be leading not away from federal law but rather toward a general federal workmen's compensation law. ${ }^{63}$ The Federal Government has occupied the field of wages, hours, child labor, and labor relations. $^{64}$ There can be no doubt that a Federal Workers' Injury Law would be upheld as constitutional. Such a statute, to be sure, would not eliminate all apparent inequality. Being confined by the limits of the interstate commerce clause, however liberally construed, the federal law could probably not cover enterprises of the most local character. In other words, as we pointed out before, in as much as we have a federal form of government, there will be inequalities created-and justifiable -by the very fact of federalism. Moreover, the law might choose, as the Wage and Hour Law does, to except categories of employers on such grounds as comparative

\footnotetext{
"o See I Larson, The Law of Workmen's Compensation 36-39 (I952); Samuei B. Horovitz, InJURY AND DEATH UNDER WORKMEN's COMPENSATION LAWS 6-IO (I944).

${ }^{\circ 0}$ Cf. Ives v. South Buffalo Ry., 201 N. Y. 27x, 94 N. E. 431 (I9II), holding the first New York workmen's compensation law unconstitutional.

${ }^{01}$ See American Bar Association resolution, 74 A. B. A. REp. 108 (1949) (favoring federal workmen's compensation for railroad workers and seamen); Pollack, Workmen's Compensation for Work Injuries and Diseases, 36 CoRNell L. Q. 236, 264 (1951) (same); Richter and Forer, Federal Employers' Liability Act-A Real Compensatory Law for Railroad Workers, 36 CoRNeLL L. Q. 203 (195I) (favoring retention of FELA); Horovitz, The American Bar Association Resolution to Abolish the FELA and the Jones Act, 5 NACCA L. J. II (I950) (same). And see 2 LARson, op. cit. stupra note 26 at $438-444$.

os Quite aside from the evidently undesirable solution of letting a railroad man's compensation depend on the law of the state in which the injury occurred, many instances of work injuries, notably occupational diseases, would defy any attempt to be geographically imputed to a given area.

${ }^{03}$ It may be apposite to remember that our last great Republican president, Theodore Roosevelt, raised just that postulate- to enact a general federal workmen's compensation law. 42 CoNG. REc. 73 (rg07).

Supra, note 51 .
} 
unimportance or low accident rates, and the law might exempt from its provisions all non-hazardous occupations. ${ }^{65}$ All these and other resultant inequalities could be justified in some objective, tenable fashion. The new Congress may carefully weigh and choose among professions and groups of industrial hazards and select those best suited for nation-wide uniformity, that is, for federal law. But to continue the singling out of railroad men for federal treatment, because that was as far as we could get in 1908 , is the perpetuation of an archaic piece of legislation. ${ }^{60}$

It is obvious that a modern workers' injury act must be a true work-injury law, where the claim for recovery arises if the injury was connected with the employment. $^{67}$ The FELA's still prevailing recovery-for-negligence pattern, however much whittled down by legislative amendment and judicial interpretation, is not likely to be imitated again. Even if under liberal construction some railroad employees at times recover for acts or omissions that would not be regarded as giving rise to a cause of ordinary negligence action, the fact still remains that others cannot recover for their work injuries for want of a showing of negligence. ${ }^{68}$ In other words, if we agree with the words of Theodore Roosevelt that to put the burden of loss of life or limb on the victim or his family is a form of social injustice, ${ }^{\text {on }}$ only a law in the nature of workmen's compensation can be the remedy. Negligence suits with doubtful outcome do not eliminate "social injustice." As we support, by social security, the aged worker, thus must we take care of the one who is crippled.

Court or board-that is the often ventilated question. ${ }^{70}$ Until the elaborate Illinois study by Conard and $\mathrm{Mehr},{ }^{71}$ the probably prevailing opinion regarded court procedures as cumbersome, slow, and more expensive than industrial accident boards. The Illinois research study, however, tends to show the opposite-that, at least in that state, court procedures under the present FELA are cheaper, not essentially slower, and financially more beneficial to the injured worker than administrative procedures under the state workmen's compensation law. A recent, well-documented California study, ${ }^{72}$ on the other hand, demonstrates that-at least

of This, at least, is a frequent pattern of exclusion from workmen's compensation coverage. U. S. Bureau of Labor Standards Bult. No. 125 , op. dit. supra, note 26 , at $4-6$. I have often doubted the justification of this exemption. If an occupation is non-hazardous, the compensation insurance premium will be lower; but, as far as the individual goes, his work injury is none the easier to bear because the probability ratio of its occurrence was lower!

${ }^{\circ 6}$ See Prosser on Torts 547-8 (194I). And see the criticism by Mr. Justice Frankfurter, concurring in Wilkerson v. McCarthy, 336 U. S. 53, at 64 (1949); concurring in Urie v. Thompson, 337 U. S. 163, at 196 (1949); Jaffe, book review, 4 J. LegAL Educ. 472 (1952).

"Whether the standard workmen's compensation law phrase "arising out of and in the course of the employment" constitutes as desirable a delineation of work injuries as its originators in imitation of the English law seem to have thought, is open to doubt. See Cardillo v. Liberty Mutual Ins. Co. 330 U. S. 469, 479 (1947); Horovitz, The Litigious Phrase: "Arising out of" Employment, 3 NACCA L. J. I5 (1949); Bear, Survey of the Legal Profession-Workmen's Compensation and the Lasuyer, 51 CoL. L. REV. 965,968 (195I).

${ }^{88}$ See the cases supra, note 39 . And see Pollack, supra, note 38 ; Miller, supra, note I4.

${ }^{\circ 0}$ Supra, note 63 .

${ }^{70}$ For authorities on both sides of the controversy see the literature cited stpra, note $6 \mathrm{r}$.

${ }^{71}$ Supra, note 37. See, however, Conard, Workmen's Compensation: Is It More Efficient Than Employer's Liability?, 38 A. B. A. J. I0rx, 1058 (1952) ("The Illinois study does not show that federal employers' liability is a better system than workmen's compensation.")

${ }^{72}$ Bancroft, supra, note 37 . 
in California-"the compensation system is remarkable for its efficiency and speed"; that hearings on the average consume but one hour; that more than $5^{\circ}$ per cent of the claims are generally decided administratively within three months after filing; and, last but not at all least, that the average attorney's fee awarded by the Commission is no more than $\$$ 10o.Io. At any rate, there can be no doubt that boards are better adapted for "streamlining," such as through the introduction of the referee system, than the courts.

Be this as it may, if the proposed injured workers' law is to operate regardless of negligence, it is not likely that its administration will be left to the already overburdened courts, federal or state. The parties' legitimate desire to have a jury trial in tort cases centers around two phases of the litigation: the negligence issue and the amount of damages. ${ }^{73}$ The former would be immaterial, and the latter determined by compensation rates whose adequacy must be up to the people, i.e., to Congress. In other words, the work-injury law applying to all, or most, or at least many, interstate-commerce-affecting workers must be a piece of social legislation whose benefits accrue independent of fault or defective appliances and whose awards are uniform as to similar situations. ${ }^{74}$

This proposal does not mean that negligence should be encouraged. An employer who negligently injures his employee, e.g., by culpably failing to give him a safe place to work, should be liable supplementarily to workmen's compensation. This is the law in foreign countries and it has been demanded in this country for a long time. Surely, if an employer is careless toward his employees' safety, there is no reason why he should not pay damages if an injury results, ${ }^{\mathbf{7 5}}$ even though his enterprise is covered by workmen's compensation, which, under social laws operating regardless of fault, attempt, not to compensate for actual damages, but merely to enable the injured worker to continue to exist. Whether, however, the employer's negligence liability in supplement of compensation ought to be restricted to "gross" negligence is a question of legislative policy not to be discussed here. In its favor it might be argued that it is a purpose correlative to the social function of workmen's compensation law to take away from employers the burden of suitsoften unwarranted-based on a strained construction of the term negligence and that therefore the employer should remain immune to workers' ordinary negligence

\footnotetext{
${ }^{73}$ High verdicts, however, can be had also in non-jury cases, such as under the Federal Tort Claims Act. For very recent examples, chosen at random, see Feathersmith v. United States, 104 F. Supp. 226 (E. D. Pa. 1952) ( $\$ 56,000$ for injuries of woman earning $\$ 46.80$ a week); United States v. Grigalauskas, I95 F. 2d 494 (Ist Cir. 1952) (\$94,000 for back injuries); Cotant v. United States, ro3 F. Supp. $77^{\circ}$ (D. Idaho 1952) ( $\$ 55,000$ for child's ruptured urethra).

'The pattern of the Longshoremen's Act or the FECA, supra, notes 8 and 9, may be followed. Probably, however, neither the primacy of state law of the former act (see supra, note 3I) nor the exclusion of judicial review under the latter would be adopted. The experience of the Longshoremen's Act is not always encouraging. E.g., Mattison v. Brown, I97 F. 2d 4I4 (7th Cir. I952) (finding against the claimant by Commissioner though there was "absolutely no evidence" in support of the denial).

${ }_{70}$ This solution was favored by Mr. Justice Brandeis, dissenting in New York Central R. R. v. Winfield, 244 U. S. 147, 154, 164-70 (1917). And see James, Social Insurance and Tort Liability: The Problem of Alternative Remedies, 27 N. Y. U. L. REv. 537 (1952).
} 
actions counting on sympathetic juries. If the limitation is adopted, however, care should be taken that the courts-or whoever will be the tribunals to hear and decide negligence suits in supplementation of compensation-do not construe "gross" negligence in such a manner that practically nothing is left for a cause of action short of quasi-criminal conduct. ${ }^{76}$

This and other details may be left to legal policy; but the situation that a mine worker, totally and permanently disabled in an industrial accident, in, say, $\mathrm{W}_{\mathrm{y}-}$ oming, receives a maximum benefit of $\$ 3,800$ (!), whereas a similarly crippled railroad worker may get either nothing at all, if no negligence or faulty safety appliances can be proved, ${ }^{77}$ or anything between very little and up to, maybe, $\$ 150,000$ or more, ${ }^{78}$ depending on the accidental fact of the jurors' moods and economic opinions -this situation has neither sense nor justice from any point of view.

${ }^{70}$ See e.g., Day v. Gold Star Dairy, 307 Mich. 383, I2 N. W. 2d 5 (1943).

${ }^{77}$ See the cases supra, note 39 , which of course can be multiplied ad libitum and to which the many unreported decisions and dismissals must be added as well as those railroad work-injuries that never reach the courts.

${ }^{78}$ For compilations of recent awards, both reported and unreported, above $\$ 50,000$, see 9 NACCA L. J. 247 (1952); 8 NACCA L. J. 230 (I95I); 7 NACCA L. J. 222 (195II); 6 NACCA L. J. 204 (I950). 